\title{
PRIORITAS PENANGANAN LOKASI RAWAN KECELAKAAN (LRK) DI PROVINSI SUMATERA UTARA
}

\author{
Budi Hartanto Susilo $^{1}$, Lutfiardi Wahyu Cahyadi ${ }^{2}$ \\ ${ }^{1}$ Dosen Tetap, Program Studi Teknik Sipil, Fakultas Teknik, Universitas Kristen Maranatha \\ ${ }^{2}$ Alumni, Program Studi Teknik Sipil, Fakultas Teknik, Universitas Kristen Maranatha \\ Jalan Prof. drg. Suria Sumantri, MPH. No. 65 Bandung 40164 \\ Email:budiharsus@yahoo.com
}

\begin{abstract}
ABSTRAK
Provinsi Sumatera Utara adalah provinsi ke lima dengan jumlah kecelakaan tertinggi setelah Jawa Timur, Jawa Tengah, Jawa Barat, dan Sulawesi Selatan dengan jumlah korban meninggal dunia 1649 jiwa, korban luka berat 1759 jiwa, korban luka ringan 5897 jiwa, dan jumlah kerugian sebesar Rp.12.157.821.000,-. Begitu banyak lokasi kecelakaan yang terjadi berdasarkan data Polda Sumatera Utara. Oleh karena itu perlu dilakukan pemrioritasan penanganan lokasi rawan kecelakan (LRK) di Provinsi Sumatera Utara. Jumlah kecelakaan dari 5335 kejadian kecelakaan kemudian dipilih menjadi 2587 kejadian berada di ruas Jalan Nasional, penyaringan kejadian memenuhi kriteria $\geq 2$ kejadian tiap lokasi menjadi 438 LRK, kemudian dilakukan analisis dengan metode angka ekivalen kecelakaan (AEK), tingkat kecelakaan (Tk), dan Upper Control Limit (UCL) sehingga diperoleh 52 LRK. Dengan penggabungan 24 lokasi tipikal dan lokasi yang berdekatan maka dihasilkan 40 LRK. Selanjutnya 40 LRK tersebut disurvei rinci dan disusun Rencana Teknik Akhir yang lengkap termasuk Rencana Anggaran Biayanya. Pada akhirnya prioritas penanganan disesuaikan dengan dana yang tersedia.
\end{abstract}

Kata Kunci: Lokasi Rawan Kecelakaan, prioritas penanganan LRK.

\begin{abstract}
North Sumatra Province is the fifth province in Indonesia with the highest number of accidents after East Java, Central Java, West Java and South Sulawesi with 1649 deaths, 1759 serious injuries, 5897 minor injuries, and total loss of Rp.12,157,821,000, -. There are so many locations of accidents happen based on North Sumatra Regional Police data. Therefore it is necessary to prioritize the handling of black spot in North Sumatra Province. The number of accidents from 5335 accidents events was then selected to be 2587 events on the National Road section, selecting events fulfilled the criteria $\geq 2$ events per location to 438 black spot, then analyzed using equivalence accident number (EAN), accident rate, and Upper Control Limit (UCL) in order to obtain 52 black spot. By combining 24 typical locations and adjacent locations, 40 black spot are produced. Furthermore, 40 black spot were surveyed in detail and a complete Final Engineering Plan was prepared including the Budget Plan. In the end the priority of handling is adjusted to the available funds.
\end{abstract}

Keywords: black spot, priority for handling black spot

\section{PENDAHULUAN}

Jumlah kecelakaan di Provinsi Sumatera Utara masih dinilai cukup tinggi, yaitu sebesar 6.276 kejadian pada tahun $2016^{1}$ dan 4.803 kejadian pada tahun $2017^{2}$. Hal ini menunjukkan perlu adanya upaya perbaikan-perbaikan dari berbagai pihak untuk meminimalkan jumlah kecelakaan. Pemerintah wajib menjamin terciptanya keselamatan

\footnotetext{
${ }^{1}$ Data Polda Sumatera Utara, dikutip dari regional.kompas.com (2017)

${ }^{2}$ Data Polda Sumatera Utara, Dikutip dari news.okezone.com (2018)

Prioritas Penanganan Lokasi Rawan Kecelakaan (LRK) di Provinsi Sumatera Utara (Budi Hartanto Susilo, Lutfiardi Wahyu Cahyadi)
} 
Lalu Lintas dan Angkutan Jalan artinya pemerintah bertanggung jawab untuk menghindarkan para pengguna jalan dari risiko kecelakaan.

Prioritas Penanganan Lokasi Rawan Kecelaaan (LRK) di Provinsi Sumatera Utara merupakan kegiatan kajian (studi) mengenai keberadaan LRK (Lokasi Rawan Kecelakaan). Kegiatan ini merupakan kegiatan yang bertujuan mengurangi resiko terjadinya kecelakaan. Dalam melakukan kegiatan ini tentu harus mengacu pada literatur yang ada, baik literatur hukum atau akademik. Untuk melaksanakan kegitan ini, diperlukan tenaga ahli yang kompeten di bidangnya sehingga dalam pelaksanaannya akan membutuhkan berbagai disiplin ilmu.

\section{STUDI LITERATUR}

Kecelakaan lalu lintas adalah suatu peristiwa di Jalan yang tidak diduga dan tidak disengaja melibatkan kendaraan dengan atau tanpa pengguna jalan lain yang mengakibatkan korban manusia dan/atau kerugian harta benda. (UU No.22 Tahun 2009).

Program nasional Rencana Umum Nasional Keselamatan Lalu Lintas Angkutan Jalan (RUNK LLAJ) terdiri dari 5 pilar yaitu:

I. Pilar 1 (satu) yaitu sistem yang berkeselamatan;

II. Pilar 2 (dua) yaitu jalan yang berkeselamatan;

III. Pilar 3 (tiga) yaitu kendaraan yang berkesalamatan;

IV. Pilar 4 (empat) yaitu pengguna jalan yang berkeselamatan;

V. Pilar 5 (lima) yaitu penanganan korban kecelakaan.

Berdasarkan Pd. T-09-2004-B, Departemen Permukiman dan Prasarana Wilayah, Lokasi Rawan Kecelakaan (LRK) adalah suatu lokasi dimana angka kecelakaan tinggi dengan kejadian kecelakaan berulang dalam suatu ruang dan rentang waktu yang relatif sama yang diakibatkan oleh suatu penyebab tertentu. Artinya identifikasi Lokasi Rawan Kecelakaan dilakukan dengan mencari lokasi (persimpangan, jembatan, dan ruas jalan) dimana terjadi kecelakaan lalu lintas $\geq 2$ kali dalam 1 tahun.

Pemeringkatan LRK dilakukan untuk menentukan LRK terburuk yang perlu mendapatkan prioritas penanganan terlebih dahulu. Pengurutan tersebut didasarkan pada jumlah kejadian kecelakaan terbobot terhadap klasifikasi korban kecelakaan (metode Angka Ekivalen Kecelakaan (AEK)). Metode ini dipililih karena data yang diperlukan adalah data kecelakaan yang tercatat di Ditlantas Polda Sumatera Utara dengan angka ekivalensi yang sudah ditetapkan sehingga analisisnya dapat dipertanggungjawabkan dan tidak memakan waktu yang lama. Tingkat kecelakaan digunakan untuk menentukan 
prioritas LRK yang memiliki nilai AEK yang sama. Sementara banyaknya LRK yang memerlukan penanganan secara signifikan ditentukan berdasarkan kontrol statistik menggunakan Upper Contol Limit.

Teknik mengidentifikasi peringkat LRK dengan metode AEK merupakan perhitungan Angka Kecelakaan Terbobot (AKT) pada setiap LRK berdasarkan data jumlah kecelakaan yang terklasifikasi berdasarkan tingkat keparahan korbannya. Ada beberapa jenis kecelakaan berdasarkan tingkat keparahan korban sehingga angka kecelakaan perlu ditimbang dengan Angka Ekivalen Kecelakaan (AEK). AEK dihitung dengan membandingkan estimasi kerugian ekonomi yang disebabkan oleh berbagai tingkat kecelakaan, yaitu korban kematian (MD), luka berat (LB), luka ringan (LR), atau kerugian material (KM). Ada beberapa nilai-nilai AEK disarankan seperti yang ditunjukan pada Tabel 1.

Tabel 1. Nilai Angka Ekivalen Kecelakaan (AEK)

\begin{tabular}{|c|c|c|c|c|c|c|c|c|c|}
\hline $\begin{array}{c}\text { Tingkat } \\
\text { Kecelakaan }\end{array}$ & USA & $\begin{array}{c}\text { Puslitbang } \\
\text { Jalan }\end{array}$ & $\begin{array}{c}\text { Ditjen } \\
\text { Hubdat }\end{array}$ & $\begin{array}{c}\text { Ditjen } \\
\text { Hubdat } \\
\text { (Recently) }\end{array}$ & Polri & SP & BHS & $\begin{array}{c}\text { Rata- } \\
\text { rata }\end{array}$ & $\begin{array}{c}\text { Binkes } \\
\text { (Nilai } \\
\text { yang } \\
\text { digunakan) }\end{array}$ \\
\cline { 2 - 11 } & $(1)$ & $(2)$ & $(3)$ & $(4)$ & $(5)$ & $(6)$ & $(7)$ & $(8)$ & $(9)$ \\
\hline MD & 900 & 12 & 12 & 12 & 10 & 325 & 300 & 111 & 100 \\
\hline LB & 100 & 3 & 7 & 5 & 5 & 20 & 15 & 15 & 20 \\
\hline LR & 10 & 3 & 3 & 1 & 1 & 6 & 3 & 3 & 5 \\
\hline KM & 1 & 1 & 1 & 1 & 1 & 1 & 1 & 1 & 1 \\
\hline
\end{tabular}

Deskripsi: Puslitbang Jalan $=$ Pusat Penelitian dan Pengembangan Jalan; Ditjen Hubdat $=$ Direktorat Jenderal Perhubungan Darat; Polri = Polisi Republik Indonesia; SP = Sigit Priyanto; BHS = Budi Hartanto Susilo; Binkes $=$ Direktorat Pembinaan Keselamatan.

Kerugian material dalam hal ini merupakan jumlah kecelakaan yang mengakibatkan kerugian material (kerusakan kendaraan, sarana, prasarana jalan, dsb) tanpa menimbulkan korban meninggal dunia, luka berat, maupun luka ringan.

Dengan menggunakan nilai rata-rata AEK yang dirasionalisasikan, seperti ditampilkan pada tabel, nilai AKT dari lokasi dihitung sebagai berikut:

$$
A K T=\Sigma M D \times A E K_{M D}+\Sigma L B \times A E K_{L B}+\Sigma L R \times E A N_{L R}+\Sigma K M \times A E K_{K M}
$$

dengan:

$$
\begin{array}{ll}
\text { AKT } & =\text { Angka Kecelakaan Terbobot } \\
\text { AEK } & =\text { Angka Ekivalen Kecelakaan } \\
\text { MD } & =\text { Korban Meninggal Dunia } \\
\text { LB } & =\text { Korban Luka Berat } \\
\text { LR } & =\text { Korban Luka Ringan } \\
\text { KM } & =\text { Kerugian Material }
\end{array}
$$


Tingkat Kecelakaan $\left(\mathrm{T}_{\mathrm{K}}\right)$ adalah jumlah kejadian kecelakaan per 100.000 juta perjalanan per kilometer. Perhitungan tingkat kecelakaan dibedakan untuk simpang dan ruas jalan, yaitu:

1. Tingkat kecelakaan lalu lintas untuk persimpangan:

$$
T_{K}=\frac{F_{K} \times 10^{8}}{V_{L L P} \times n \times 0,1 \times 365} \quad,(100 \mathrm{JPKP})
$$

dengan:

$$
\begin{array}{ll}
\mathrm{T}_{\mathrm{K}} & =\text { tingkat kecelakaan, 100JPKP } \\
\mathrm{F}_{\mathrm{K}} & =\text { frekuensi kecelakaan di persimpangan untuk } n \text { tahun data. } \\
\mathrm{V}_{\mathrm{LLP}} & \text { volume lalu lintas persimpangan. } \\
\mathrm{n} & \text { jumlah tahun data. } \\
\text { 100JPKP }= & \text { satuan tingkat kecelakaan/Seratus Juta Perjalanan Kendaraan Per- } \\
& \text { Kilometer. }
\end{array}
$$

2. Tingkat kecelakaan untuk ruas jalan:

$$
T_{K}=\frac{F_{K} \times 100^{8}}{L H R_{T} \times n \times L \times 365} \quad,(100 \mathrm{JPKP})
$$

dengan:

$$
\begin{array}{ll}
\mathrm{T}_{\mathrm{K}} & =\text { tingkat kecelakaan, 100JPKP } \\
\mathrm{F}_{\mathrm{K}} & =\text { frekuensi kecelakaan di persimpangan untuk } n \text { tahun data. } \\
\mathrm{LHR}_{\mathrm{T}} & =\text { volume lalu lintas rata-rata. } \\
\mathrm{n} & =\text { jumlah tahun data. } \\
\mathrm{L} & =\text { panjang ruas jalan. Km } \\
\text { 100JPKP }= & \text { satuan tingkat kecelakaan/Seratus Juta Perjalanan Kendaraan Per- } \\
& \text { Kilometer. }
\end{array}
$$

Penentuan Prioritas Lokasi Rawan Kecelakaan menggunakan statistik kendali mutu sebagai control-chart UCL (Upper Control Limit). Segmen ruas jalan dengan tingkat kecelakaan yang berada di atas garis UCL didefinisikan sebagai lokasi rawan kecelakaan. Rumus UCL sebagai berikut:

$$
\mathrm{UCL}=\lambda+[\sqrt{ } 2,576(\lambda /(\mathrm{m})]+[0,829 /(\mathrm{m})]+[1 / 2(\mathrm{~m})]
$$

dengan:

$\mathrm{UCL}=$ garis kendali batas atas 
$\lambda=$ rata-rata tingkat kecelakaan dalam satuan kecelakaan per eksposure

$\mathrm{m} \quad=$ satuan eksposure (Nilai AEK)

Note: Rumus-rumus 1,2,3,4 diambil dari Pusat Penelitian dan Pengembangan Prasarana Transportasi, 2004, Pd T-09-2004-B.

\section{METODE PENELITIAN}

Untuk menentukan LRK terpilih di ruas Jalan Nasional Provinsi Sumatera Utara diperlukan data-data informasi yang diperoleh baik dari instansi-instansi maupun lapangan. Data-data tersebut mencakup:

a. Data kecelakaan lalu lintas di Provinsi Sumatera Utara satu tahun terakhir;

b. Data LHR di ruas Jalan Nasional Provinsi Sumatera Utara;

c. Data Inventarisasi Jalan di ruas Jalan Nasional Provinsi Sumatera Utara;

d. Data pengamatan kondisi eksisting di lokasi-lokasi yang sering terjadi kecelakaan, memiliki alinyemen yang ekstrim, ramai pejalan kaki, jarak pandang yang pendek, dan bahaya sisi jalan.

Maka setelah melakukan survei institusional kepada: Direktorat Lalu Lintas Kepolisian Daerah Provinsi Sumatera Utara, Dinas Perhubungan Provinsi Sumatera Utara, Balai Pengelola Transportasi Darat Provinsi Sumatera Utara, Balai Besar Pelaksanaan Jalan Nasional Wilayah II Provinsi Sumatera Utara, Dinas Bina Marga Provinsi Sumatera Utara, dan Satuan Kerja Non Vertikal Tertentu Perencanaan dan Pengawasan Jalan dan Jembatan Nasional Provinsi Sumatera Utara.

Setelah semua data yang dibutuhkan terkumpul, maka dilakukan pengolahan data berupa pengelompokan dan pemilihan lokasi kejadian kecelakaan di ruas Jalan Nasional, kemudian penyaringan dan pemeringkatan LRK dengan metode AEK, Tk, dan UCL. Selanjutnya penggabungan lokasi tipikal dan berdekatan yang kemudian diklasifikasikan menjadi lokasi di ruas jalan antar kota dan jalan perkotaan. LRK terpilih yang selanjutnya perlu di survei detail lanjutan untuk dapat menyusun usulan penanganan, rencana teknik akhir, dan rencana anggaran biayanya.

\section{HASIL ANALISIS DAN PEMBAHASAN}

Proporsi agregat campuran didapatkan dengan melakukan analisis ayakan berdasarkan agregat yang digunakan. Agregat yang digunakan adalah agregat kasar, agregat halus, dan bahan pengisi. Gradasi agregat gabungan untuk campuran aspal dapat dilihat pada Tabel 2.2

Prioritas Penanganan Lokasi Rawan Kecelakaan (LRK) di Provinsi Sumatera Utara (Budi Hartanto Susilo, Lutfiardi Wahyu Cahyadi) 
Data sekunder kecelakaan lalu lintas diperoleh dari data Ditlantas Polda Sumatera Utara, dari Tahun 2017 sampai bulan Mei 2018. Data tersebut menyatakan sebanyak 5335 kejadian yang tersebar di seluruh jaringan jalan di Provinsi Sumatera Utara. Diantaranya terdapat 2587 kejadian kecelakaan terjadi di ruas jalan Nasional di Provinsi Sumatera Utara. Dari 2587 kejadian kecelakaan tersebut setelah dipilah dan dipilih menurut kriteria LRK terdapat 438 lokasi yang dikategorikan sebagai lokasi rawan kecelakaan dengan jumlah kejadian kecelakaan lebih besar sama dengan dua (jumlah kejadian $\geq 2$ ). Dari 439 LRK diurutkan berdasarkan AEK dan Tk dengan syarat nilai AEK diatas nilai UCL, sehingga terpilih lah 52 LRK. Kemudian dari 52 LRK tersebut terdapat beberapa LRK yang berdekatan dan tipikal sehingga terpilih 40 LRK.

Contoh perhitungan:

Kecelakaan yang terjadi pada ruas jalan Jalinsum KM 34 - 35 Medan - Tebing Tinggi Ling. Pasiran Kec. Perbaungan Kab. Serdang Bedagai mengakibatkan jumlah kecelakaan sebanyak 15 kali dengan korban $\mathrm{MD}=5, \mathrm{LB}=6, \mathrm{LR}=20$ dengan $\mathrm{LHR}=$ 17870 smp/jam, sehingga nilai AEK dan Tk dapat dihitung sebagai berikut:

$$
\begin{aligned}
\text { AEK } & =100 \mathrm{MD}+20 \mathrm{LB}+5 \mathrm{LR}+1 \mathrm{JK} \\
\mathrm{AEK} & =(100 \times 5)+(20 \times 6)+(5 \times 20)+(1 \times 15) \\
& =735 \\
\mathrm{Tk} & =15 / 17870 \times 10000=8,39
\end{aligned}
$$

Jadi, nilai AEK dan Tk pada ruas jalan Jalinsum KM 34 - 35 Medan - Tebing Tinggi Ling. Pasiran Kec. Perbaungan Kab. Serdang Bedagai adalah 735 dan 8,39.

Dengan jumlah total nilai AEK $=69420$ pada 439 LRK, maka nilai rata-rata $(\lambda)$ dapat dihitung sebagai berikut:

$\lambda=69420 / 439=158,13$

Faktor probabilitas $(\psi)=2,576$

Untuk ruas jalan Jalinsum KM 34 - 35 Medan - Tebing Tinggi Ling. Pasiran Kec. Perbaungan Kab. Serdang Bedagai dengan nilai AEK $(m)=735$, maka nilai UCL dapat dihitung sebagai berikut:

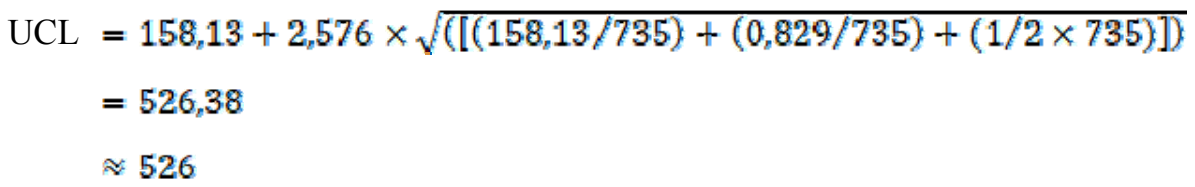

Jadi, nilai batas kontrol dengan metode UCL pada ruas jalan Jalinsum KM 34 - 35 Medan - Tebing Tinggi Ling. Pasiran Kec. Perbaungan Kab. Serdang Bedagai adalah 
sebesar 526 angka kecelakaan. Secara grafis identifikasi LRK dengan metode UCL dapat dilihat Gambar 1.

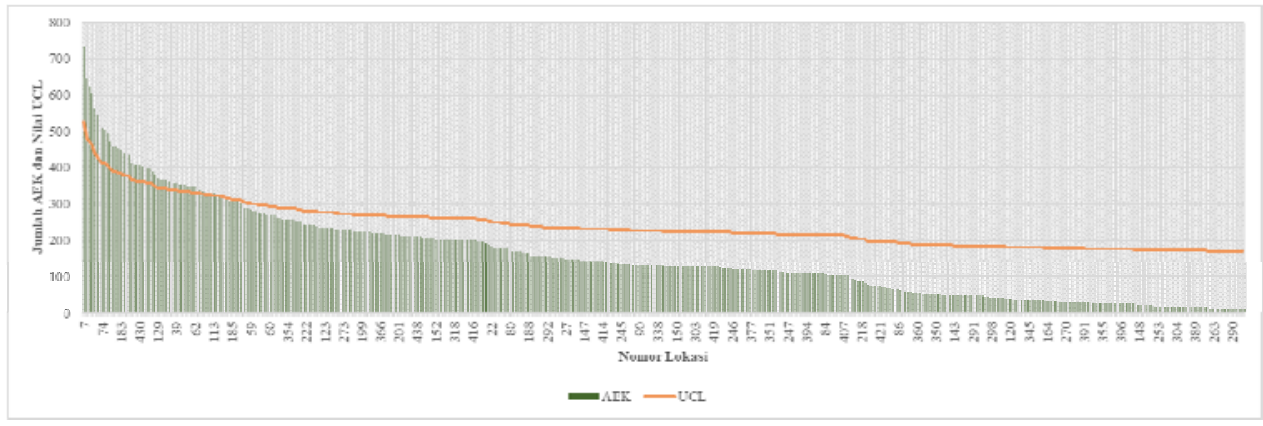

Gambar 1. Identifikasi LRK dengan Metode UCL

Dari pemeringkatan yang telah dilakukan di 439 LRK, didapatkan LRK diatas nilai UCL adalah sebanyak 52 LRK, jumlah tersebut kemudian diseleksi kembali dengan menggabungkan lokasi tipikal berdekatan maka diperoleh 40 LRK terpilih dengan hasil perhitungan yang dapat dilihat pada Tabel 2, nilai tersebut sesuai dengan dana yang tersedia atau kesepakatan dengan Direktorat Pembinaan Keselamatan.

Dari 40 LRK terpilih selanjutnya dapat diusulkan penanganannya. Adapun usulan penanganan pada ruas jalan Jalinsum KM 34 - 35 Medan - Tebing Tinggi Ling. Pasiran Kec. Perbaungan Kab. Serdang Bedagai dapat dilihat pada Tabel 3, berdasarkan kesepakatan bersama untuk penanganan analisis detail ideal. Kemudian hasil akhir yang diperoleh adalah gambar Rencana Teknik Akhir (Detail Engineering Design) yang dapat dilihat pada Gambar 2 dan Gambar 3 sesuai dengan gambar eksisting dan penanganan rencana yang diusulkan. Setelah tersusunnya usulan penanganan dan gambar rencana teknik akhir, selanjutnya disusun rencana anggaran biaya penanganan.

Pada dasarnya metode perhitungan biaya merupakan volume atau kuantitas yang didapat dari gambar desain dikalikan dengan hasil analisis harga satuan yang terdiri dari harga-harga upah, alat, dan material, sehingga didapat harga standar dan jumlah biaya estimasi tersebut. Harga satuan telah dikalikan dengan koefisien kemahalan standar biaya Kementerian Perhubungan Tahun 2014 (PM 78 Tahun 2014) berdasarkan indeks kemahalan konstruksi. Adapun contoh rincian rencana anggaran biaya penanganan dapat dilihat pada Tabel 4 . 
Tabel 2. 40 LRK Terpilih

\begin{tabular}{|c|c|c|c|c|c|c|c|c|c|c|c|}
\hline \multirow{2}{*}{ Peringkat } & \multirow{2}{*}{ Lokasi } & \multirow{2}{*}{ No. Ruas } & \multirow{2}{*}{ Nama Ruas } & \multirow{2}{*}{ LHR } & \multirow{2}{*}{$\begin{array}{c}\text { Jumlah } \\
\text { Laka }\end{array}$} & \multicolumn{3}{|c|}{ Korban } & \multirow[t]{2}{*}{ Nilai AEK } & \multirow[t]{2}{*}{ Tk } & \multirow[t]{2}{*}{$\begin{array}{c}\text { Segmen } \\
\text { Jalan }\end{array}$} \\
\hline & & & & & & MD & LB & LR & & & \\
\hline (1) & (2) & (3) & (4) & (5) & (6) & (7) & (8) & (9) & $\begin{array}{c}(10)= \\
(7) * 100+ \\
(8) * 20+ \\
(9) * 5+(6) * 1\end{array}$ & $\begin{array}{c}(11)= \\
((6) /(5))^{*} 1 \\
0.000\end{array}$ & (12) \\
\hline 1 & $\begin{array}{l}\text { Jalinsum KM } 34 \\
\text { - } 35 \text { Medan - } \\
\text { Tebing Tinggi } \\
\text { Ling. Pasiran } \\
\text { Kec. Perbaungan } \\
\text { Kab. Serdang } \\
\text { Bedagai }\end{array}$ & 010 & $\begin{array}{c}\text { TUGU KOTA } \\
\text { LUBUK PAKAM } \\
\text { - BTS. KAB. } \\
\text { SERDANG } \\
\text { BEDAGAI KM } \\
5,1-6,1\end{array}$ & 17870 & 15 & 5 & 6 & 20 & 735 & 8.3940 & $\begin{array}{l}\text { Antar } \\
\text { Kota }\end{array}$ \\
\hline 2 & $\begin{array}{l}\text { Jalinsum KM } 43 \\
-44 \text { Medan - } \\
\text { Tebing Tinggi } \\
\text { Kec. Perbaungan } \\
\text { Kab. Serdang } \\
\text { Bedagai }\end{array}$ & 012 & $\begin{array}{c}\text { PERBAUNGAN - } \\
\text { BTS. KAB. DELI } \\
\text { SERDANG/SEI } \\
\text { BULUH KM 5,9 - } \\
6,9\end{array}$ & 17870 & 9 & 5 & 5 & 7 & 644 & 5.0364 & $\begin{array}{c}\text { Antar } \\
\text { Kota }\end{array}$ \\
\hline 3 & $\begin{array}{l}\text { Jalinsum Medan } \\
\text { - Rantau Prapat } \\
\text { KM } 256 \text { - } 257 \\
\text { Kec. Aek Natas } \\
\text { Kab. Labuhan } \\
\text { Utara }\end{array}$ & 024 & $\begin{array}{l}\text { AEK KANOPAN - } \\
\text { BTS. KOTA } \\
\text { RANTAU } \\
\text { PRAPAT KM } 37,2 \\
-38,2\end{array}$ & 5632 & 4 & 5 & 3 & 12 & 624 & 7.1023 & $\begin{array}{l}\text { Antar } \\
\text { Kota }\end{array}$ \\
\hline
\end{tabular}




\begin{tabular}{|c|c|c|c|c|c|c|c|c|c|c|c|}
\hline \multirow{2}{*}{ Peringkat } & \multirow{2}{*}{ Lokasi } & \multirow{2}{*}{ No. Ruas } & \multirow{2}{*}{ Nama Ruas } & \multirow{2}{*}{ LHR } & \multirow{2}{*}{$\begin{array}{c}\text { Jumlah } \\
\text { Laka }\end{array}$} & \multicolumn{3}{|c|}{ Korban } & \multirow[t]{2}{*}{ Nilai AEK } & \multirow[t]{2}{*}{ Tk } & \multirow[t]{2}{*}{$\begin{array}{c}\text { Segmen } \\
\text { Jalan }\end{array}$} \\
\hline & & & & & & MD & LB & LR & & & \\
\hline (1) & (2) & (3) & (4) & (5) & (6) & (7) & (8) & (9) & $\begin{array}{c}(10)= \\
(7) * 100+ \\
(8) * 20+ \\
(9) * 5+(6) * 1\end{array}$ & $\begin{array}{c}(11)= \\
((6) /(5))^{*} 1 \\
0.000\end{array}$ & (12) \\
\hline 4 & $\begin{array}{l}\text { Jalan Umum } \\
\text { Medan - Tanjung } \\
\text { Pura KM } 33-34 \\
\text { Kec. Stabat Kab. } \\
\text { Langkat }\end{array}$ & 004 & $\begin{array}{c}\text { BTS. KOTA } \\
\text { STABAT - BTS. } \\
\text { KOTA BINJAI } \\
\text { KM 4,8 - 5,8 }\end{array}$ & 14335 & 9 & 5 & 4 & 3 & 604 & 6.2783 & $\begin{array}{l}\text { Antar } \\
\text { Kota }\end{array}$ \\
\hline 5 & $\begin{array}{l}\text { Jl. Jamin Ginting } \\
\text { KM } 42 \text { - } 43 \text { Kec. } \\
\text { Sibolangit Kab. } \\
\text { Deli Serdang }\end{array}$ & 052 & $\begin{array}{c}\text { BTS. KOTA } \\
\text { MEDAN - BTS. } \\
\text { KAB. KARO KM } \\
25-26\end{array}$ & 5619 & 3 & 4 & 5 & 12 & 563 & 5.3390 & $\begin{array}{l}\text { Antar } \\
\text { Kota }\end{array}$ \\
\hline 6 & $\begin{array}{l}\text { Jalan Umum KM } \\
30 \text { - } 31 \text { Medan - } \\
\text { Tebing Tinggi } \\
\text { Kec. Lubuk } \\
\text { Pakam Kab. Deli } \\
\text { Serdang }\end{array}$ & 010 & $\begin{array}{c}\text { TUGU KOTA } \\
\text { LUBUK PAKAM } \\
\text { - BTS. KAB. } \\
\text { SERDANG } \\
\text { BEDAGAI KM } \\
2,1-3,1 \\
\end{array}$ & 23283 & 11 & 4 & 0 & 21 & 516 & 4.7245 & $\begin{array}{c}\text { Antar } \\
\text { Kota }\end{array}$ \\
\hline 7 & $\begin{array}{l}\text { Jalinsum Medan } \\
\text { - Aek Nabara } \\
\text { KM } 294 \text { - } 295 \\
\text { Kec. Rantau } \\
\text { Selatan Kab. } \\
\text { Labuhanbatu }\end{array}$ & $024 / 11 / K$ & $\begin{array}{c}\text { JLN. LINGKAR } \\
\text { (R. PRAPAT) KM } \\
9\end{array}$ & 7170 & 5 & 5 & 0 & 1 & 510 & 6.9735 & $\begin{array}{c}\text { Perkotaa } \\
\mathrm{n}\end{array}$ \\
\hline
\end{tabular}




\begin{tabular}{|c|c|c|c|c|c|c|c|c|c|c|c|}
\hline \multirow{2}{*}{ Peringkat } & \multirow{2}{*}{ Lokasi } & \multirow{2}{*}{ No. Ruas } & \multirow{2}{*}{ Nama Ruas } & \multirow{2}{*}{ LHR } & \multirow{2}{*}{$\begin{array}{c}\text { Jumlah } \\
\text { Laka }\end{array}$} & \multicolumn{3}{|c|}{ Korban } & \multirow[t]{2}{*}{ Nilai AEK } & \multirow[t]{2}{*}{ Tk } & \multirow[t]{2}{*}{$\begin{array}{c}\text { Segmen } \\
\text { Jalan }\end{array}$} \\
\hline & & & & & & MD & LB & LR & & & \\
\hline (1) & (2) & (3) & (4) & (5) & (6) & (7) & (8) & (9) & $\begin{array}{c}(10)= \\
(7) * 100+ \\
(8) * 20+ \\
(9) * 5+(6) * 1\end{array}$ & $\begin{array}{c}(11)= \\
((6) /(5)) * 1 \\
0.000\end{array}$ & (12) \\
\hline 8 & $\begin{array}{l}\text { Jalan Parapat } \\
\text { KM 04,5 Kec. } \\
\text { Siantar } \\
\text { Marimbun Kota } \\
\text { Pematang } \\
\text { Siantar }\end{array}$ & $065 / 11 / \mathrm{K}$ & $\begin{array}{c}\text { JLN. KE } \\
\text { PARAPAT (P. } \\
\text { SIANTAR) KM } 2\end{array}$ & 10224 & 3 & 5 & 0 & 0 & 503 & 2.9343 & $\begin{array}{c}\text { Perkotaa } \\
n\end{array}$ \\
\hline 9 & $\begin{array}{l}\text { Jalan Umum } \\
\text { Tarutung - } \\
\text { Siborongborong } \\
\text { KM } 12 \text { - } 13 \text { Kec. } \\
\text { Sipoholon Kab. } \\
\text { Taput }\end{array}$ & 034 & $\begin{array}{c}\text { SIBORONG } \\
\text { BORONG - } \\
\text { TARUTUNG KM } \\
6,5-7,5\end{array}$ & 3484 & 4 & 4 & 4 & 2 & 494 & 11.4811 & $\begin{array}{l}\text { Antar } \\
\text { Kota }\end{array}$ \\
\hline 10 & $\begin{array}{l}\text { Jalan Umum } \\
\text { Medan - } \\
\text { Tarutung KM } \\
230 \text { - 231 Kec. } \\
\text { Balige Kab. } \\
\text { Tobasa }\end{array}$ & 068 & $\begin{array}{c}\text { SILIMBAT - BTS. } \\
\text { KAB. TAPANULI } \\
\text { UTARA KM 9,6 - } \\
10,6\end{array}$ & 7262 & 5 & 4 & 2 & 3 & 460 & 6.8852 & $\begin{array}{l}\text { Antar } \\
\text { Kota }\end{array}$ \\
\hline 11 & $\begin{array}{l}\text { Jalinsum Medan } \\
\text { - Tebing Tinggi } \\
\text { KM } 25 \text { - } 26 \text { Kec. } \\
\text { Lubuk Pakam } \\
\text { Kab. Deli }\end{array}$ & 007 & $\begin{array}{c}\text { BTS. KOTA } \\
\text { MEDAN - BTS. } \\
\text { KOTA LUBUK } \\
\text { PAKAM KM 9,5 - } \\
10,5\end{array}$ & 11970 & 9 & 4 & 0 & 10 & 459 & 7.5188 & $\begin{array}{l}\text { Antar } \\
\text { Kota }\end{array}$ \\
\hline
\end{tabular}




\begin{tabular}{|c|c|c|c|c|c|c|c|c|c|c|c|}
\hline \multirow{2}{*}{ Peringkat } & \multirow{2}{*}{ Lokasi } & \multirow{2}{*}{ No. Ruas } & \multirow{2}{*}{ Nama Ruas } & \multirow{2}{*}{ LHR } & \multirow{2}{*}{$\begin{array}{c}\text { Jumlah } \\
\text { Laka }\end{array}$} & \multicolumn{3}{|c|}{ Korban } & \multirow[t]{2}{*}{ Nilai AEK } & \multirow[t]{2}{*}{ Tk } & \multirow{2}{*}{$\begin{array}{c}\text { Segmen } \\
\text { Jalan }\end{array}$} \\
\hline & & & & & & MD & LB & LR & & & \\
\hline \multirow[t]{2}{*}{ (1) } & (2) & (3) & (4) & (5) & (6) & (7) & (8) & (9) & $\begin{array}{c}(10)= \\
(7) * 100+ \\
(8) * 20+ \\
(9) * 5+(6) * 1\end{array}$ & $\begin{array}{c}(11)= \\
((6) /(5)) * 1 \\
0.000\end{array}$ & (12) \\
\hline & Serdang & & & & & & & & & & \\
\hline 12 & $\begin{array}{l}\text { Jalinsum Medan } \\
\text { - Rantau Prapat } \\
\text { KM 156 - 157 } \\
\text { Kec. Kisaran } \\
\text { Barat Kab. } \\
\text { Asahan }\end{array}$ & $021 / 11 / \mathrm{K}$ & $\begin{array}{l}\text { JLN. SUDIRMAN } \\
\text { (KISARAN) KM } 3\end{array}$ & 11701 & 8 & 4 & 0 & 9 & 453 & 6.8370 & $\begin{array}{l}\text { Perkotaa } \\
\mathrm{n}\end{array}$ \\
\hline 13 & $\begin{array}{l}\text { Jalinsum Medan } \\
\text { - Rantau Prapat } \\
\text { KM } 263 \text { - 264 } \\
\text { Kec. Na IX-X } \\
\text { Kab. Labuhan } \\
\text { Utara }\end{array}$ & 024 & $\begin{array}{l}\text { AEK KANOPAN - } \\
\text { BTS. KOTA } \\
\text { RANTAU } \\
\text { PRAPAT KM 44,2 } \\
-43,2\end{array}$ & 5632 & 3 & 4 & 0 & 9 & 448 & 5.3267 & $\begin{array}{l}\text { Antar } \\
\text { Kota }\end{array}$ \\
\hline 14 & $\begin{array}{l}\text { Jalinsum Medan } \\
\text { - Kisaran KM } \\
138-139 \mathrm{Kec} . \\
\text { Talawi Kab. } \\
\text { Batu Bara } \\
\end{array}$ & 020 & $\begin{array}{l}\text { LIMA PULUH - } \\
\text { SEI BEJANGKAR } \\
\text { KM 16,6 - 17,6 }\end{array}$ & 7039 & 9 & 3 & 2 & 18 & 439 & 12.7859 & $\begin{array}{l}\text { Antar } \\
\text { Kota }\end{array}$ \\
\hline
\end{tabular}




\begin{tabular}{|c|c|c|c|c|c|c|c|c|c|c|c|}
\hline \multirow{2}{*}{ Peringkat } & \multirow{2}{*}{ Lokasi } & \multirow{2}{*}{ No. Ruas } & \multirow{2}{*}{ Nama Ruas } & \multirow{2}{*}{ LHR } & \multirow{2}{*}{$\begin{array}{c}\text { Jumlah } \\
\text { Laka }\end{array}$} & \multicolumn{3}{|c|}{ Korban } & \multirow[t]{2}{*}{ Nilai AEK } & \multirow[t]{2}{*}{ Tk } & \multirow[t]{2}{*}{$\begin{array}{c}\text { Segmen } \\
\text { Jalan }\end{array}$} \\
\hline & & & & & & MD & LB & LR & & & \\
\hline (1) & (2) & (3) & (4) & (5) & (6) & (7) & (8) & (9) & $\begin{array}{c}(10)= \\
(7) * 100+ \\
(8) * 20+ \\
(9) * 5+(6) * 1\end{array}$ & $\begin{array}{c}(11)= \\
((6) /(5))^{*} 1 \\
0.000\end{array}$ & (12) \\
\hline 15 & $\begin{array}{l}\text { Jalan Umum } \\
\text { Medan - Tebing } \\
\text { Tinggi KM } 22 \text { - } \\
23 \text { Kec. Tanjung } \\
\text { Morawa Kab. } \\
\text { Deli Serdang }\end{array}$ & 007 & $\begin{array}{c}\text { BTS. KOTA } \\
\text { MEDAN - BTS. } \\
\text { KOTA LUBUK } \\
\text { PAKAM KM 6,5 - } \\
7,5\end{array}$ & 11970 & 11 & 3 & 0 & 25 & 436 & 9.1896 & $\begin{array}{l}\text { Antar } \\
\text { Kota }\end{array}$ \\
\hline 16 & $\begin{array}{l}\text { Jalinsum Medan } \\
\text { - Rantau Prapat } \\
\text { KM } 188 \text { - } 189 \\
\text { Kec. Teluk } \\
\text { Dalam Kab. } \\
\text { Asahan }\end{array}$ & 023 & $\begin{array}{l}\text { SP. KAWAT - } \\
\text { AEK KANOPAN } \\
\text { KM 14,7 - 15,7 }\end{array}$ & 6521 & 2 & 4 & 0 & 2 & 412 & 3.0670 & $\begin{array}{c}\text { Antar } \\
\text { Kota }\end{array}$ \\
\hline 17 & $\begin{array}{l}\text { Jalan Umum } \\
\text { Medan - } \\
\text { Pematang } \\
\text { Siantar KM } 99 \text { - } \\
100 \text { Kec. Dolok } \\
\text { Merawan Kab. } \\
\text { Sergai }\end{array}$ & 063 & $\begin{array}{c}\text { BTS. KOTA } \\
\text { TEBING TINGGI } \\
\text { - BTS. KAB. } \\
\text { SIMALUNGUN } \\
\text { KM } 12,7-13,7\end{array}$ & 4838 & 3 & 3 & 0 & 21 & 408 & 6.2009 & $\begin{array}{c}\text { Antar } \\
\text { Kota }\end{array}$ \\
\hline 18 & $\begin{array}{l}\text { Jalan Umum } \\
\text { Medan - Gunung } \\
\text { Tua KM } 372 \text { - } \\
373 \text { Kec. Sei }\end{array}$ & 076 & $\begin{array}{c}\text { SP. KOTA } \\
\text { PINANG - BTS. } \\
\text { KAB. } \\
\text { PALUTA/BTS. }\end{array}$ & 5915 & 2 & 4 & 0 & 1 & 407 & 3.3812 & $\begin{array}{l}\text { Antar } \\
\text { Kota }\end{array}$ \\
\hline
\end{tabular}




\begin{tabular}{|c|c|c|c|c|c|c|c|c|c|c|c|}
\hline \multirow{2}{*}{ Peringkat } & \multirow{2}{*}{ Lokasi } & \multirow{2}{*}{ No. Ruas } & \multirow{2}{*}{ Nama Ruas } & \multirow{2}{*}{ LHR } & \multirow{2}{*}{$\begin{array}{c}\text { Jumlah } \\
\text { Laka }\end{array}$} & \multicolumn{3}{|c|}{ Korban } & \multirow[t]{2}{*}{ Nilai AEK } & \multirow[t]{2}{*}{ Tk } & \multirow[t]{2}{*}{$\begin{array}{c}\text { Segmen } \\
\text { Jalan }\end{array}$} \\
\hline & & & & & & MD & LB & LR & & & \\
\hline \multirow[t]{2}{*}{ (1) } & (2) & (3) & (4) & (5) & (6) & (7) & (8) & (9) & $\begin{array}{c}(10)= \\
(7) * 100+ \\
(8) * 20+ \\
(9) * 5+(6) * 1\end{array}$ & $\begin{array}{c}(11)= \\
((6) /(5))^{*} 1 \\
0.000\end{array}$ & (12) \\
\hline & $\begin{array}{l}\text { Kanan Kab. } \\
\text { Labuhanbatu } \\
\text { Selatan }\end{array}$ & & $\begin{array}{l}\text { KAB. LABUSEL } \\
\text { KM } 31-32\end{array}$ & & & & & & & & \\
\hline 19 & $\begin{array}{l}\text { Jalinsum Medan } \\
\text { - Rantau Prapat } \\
\text { KM } 194 \text { - } 195 \\
\text { Kec. Teluk } \\
\text { Dalam Kab. } \\
\text { Asahan }\end{array}$ & 023 & $\begin{array}{l}\text { SP. KAWAT - } \\
\text { AEK KANOPAN } \\
\text { KM } 20,7-21,7\end{array}$ & 6521 & 5 & 3 & 0 & 20 & 405 & 7.6675 & $\begin{array}{c}\text { Antar } \\
\text { Kota }\end{array}$ \\
\hline 20 & $\begin{array}{l}\text { Jalan Umum } \\
\text { Medan - Pangkal } \\
\text { Berandan KM } 74 \\
-75 \text { Kec. } \\
\text { Gebang Kab. } \\
\text { Langkat. }\end{array}$ & 002 & $\begin{array}{c}\text { SIMPANG } \\
\text { PANGKALAN } \\
\text { SUSU - } \\
\text { TANJUNG PURA } \\
\text { KM } 14,3-15,3\end{array}$ & 12369 & 7 & 3 & 2 & 10 & 397 & 5.6593 & $\begin{array}{c}\text { Antar } \\
\text { Kota }\end{array}$ \\
\hline 21 & $\begin{array}{l}\text { Jalinsum Medan } \\
\text { - Rantau Prapat } \\
\text { KM } 189 \text { - } 190 \\
\text { Kec. Teluk } \\
\text { Dalam Kab. } \\
\text { Asahan }\end{array}$ & 023 & $\begin{array}{l}\text { SP. KAWAT - } \\
\text { AEK KANOPAN }\end{array}$ & 6521 & 6 & 3 & 2 & 9 & 391 & 9.2010 & $\begin{array}{c}\text { Antar } \\
\text { Kota }\end{array}$ \\
\hline
\end{tabular}




\begin{tabular}{|c|c|c|c|c|c|c|c|c|c|c|c|}
\hline \multirow{2}{*}{ Peringkat } & \multirow{2}{*}{ Lokasi } & \multirow{2}{*}{ No. Ruas } & \multirow{2}{*}{ Nama Ruas } & \multirow{2}{*}{ LHR } & \multirow{2}{*}{$\begin{array}{c}\text { Jumlah } \\
\text { Laka }\end{array}$} & \multicolumn{3}{|c|}{ Korban } & \multirow[t]{2}{*}{ Nilai AEK } & \multirow[t]{2}{*}{ Tk } & \multirow[t]{2}{*}{$\begin{array}{c}\text { Segmen } \\
\text { Jalan }\end{array}$} \\
\hline & & & & & & MD & LB & LR & & & \\
\hline (1) & (2) & (3) & (4) & (5) & $(6)$ & (7) & (8) & (9) & $\begin{array}{c}(10)= \\
(7) * 100+ \\
(8) * 20+ \\
(9) * 5+(6) * 1\end{array}$ & $\begin{array}{c}(11)= \\
((6) /(5))^{*} 1 \\
0.000\end{array}$ & (12) \\
\hline 22 & $\begin{array}{l}\text { Jalinsum KM } 35 \\
-36 \text { Medan - } \\
\text { Tebing Tinggi } \\
\text { Kec. Perbaungan } \\
\text { Kab. Serdang } \\
\text { Bedagai }\end{array}$ & 011 & $\begin{array}{l}\text { BTS. KAB. DELI } \\
\text { SERDANG - } \\
\text { PERBAUNGAN }\end{array}$ & 20510 & 9 & 3 & 0 & 14 & 379 & 4.3881 & $\begin{array}{l}\text { Antar } \\
\text { Kota }\end{array}$ \\
\hline 23 & $\begin{array}{l}\text { Jalan Umum } \\
\text { Medan - } \\
\text { Tarutung KM } \\
232 \text { - 233 Kec. } \\
\text { Balige Kab. } \\
\text { Tobasa }\end{array}$ & 068 & $\begin{array}{c}\text { SILIMBAT - BTS. } \\
\text { KAB. TAPANULI } \\
\text { UTARA }\end{array}$ & 7262 & 4 & 3 & 2 & 5 & 369 & 5.5081 & $\begin{array}{l}\text { Antar } \\
\text { Kota }\end{array}$ \\
\hline 24 & $\begin{array}{l}\text { Jalinsum Medan } \\
\text { - Kisaran KM } 99 \\
\text { - 100 Kec. Sei } \\
\text { Suka Kab. Batu } \\
\text { Bara }\end{array}$ & 018 & $\begin{array}{c}\text { TANJUNG } \\
\text { KASAU - } \\
\text { INDRAPURA KM } \\
5,2-6,2\end{array}$ & 14288 & 6 & 3 & 2 & 4 & 366 & 4.1993 & $\begin{array}{l}\text { Antar } \\
\text { Kota }\end{array}$ \\
\hline 25 & $\begin{array}{l}\text { JL. Medan - } \\
\text { Binjai KM } 11 \text { - } \\
12 \text { Kec. Sunggal } \\
\text { Kab. Deli } \\
\text { Serdang }\end{array}$ & 006 & $\begin{array}{l}\text { BTS. KOTA } \\
\text { BINJAI - BTS. } \\
\text { KOTA MEDAN } \\
\text { KM } 2,1-3,1\end{array}$ & 21830 & 6 & 3 & 2 & 4 & 366 & 2.7485 & $\begin{array}{l}\text { Antar } \\
\text { Kota }\end{array}$ \\
\hline
\end{tabular}




\begin{tabular}{|c|c|c|c|c|c|c|c|c|c|c|c|}
\hline \multirow{2}{*}{ Peringkat } & \multirow{2}{*}{ Lokasi } & \multirow{2}{*}{ No. Ruas } & \multirow{2}{*}{ Nama Ruas } & \multirow{2}{*}{ LHR } & \multirow{2}{*}{$\begin{array}{c}\text { Jumlah } \\
\text { Laka }\end{array}$} & \multicolumn{3}{|c|}{ Korban } & \multirow[t]{2}{*}{ Nilai AEK } & \multirow[t]{2}{*}{ Tk } & \multirow[t]{2}{*}{$\begin{array}{c}\text { Segmen } \\
\text { Jalan }\end{array}$} \\
\hline & & & & & & MD & LB & LR & & & \\
\hline (1) & (2) & (3) & (4) & (5) & (6) & (7) & (8) & (9) & $\begin{array}{c}(10)= \\
(7) * 100+ \\
(8) * 20+ \\
(9) * 5+(6) * 1\end{array}$ & $\begin{array}{c}(11)= \\
((6) /(5))^{*} 1 \\
0.000\end{array}$ & (12) \\
\hline 26 & $\begin{array}{l}\text { Jalinsum Medan } \\
\text { - Tebing Tinggi } \\
\text { KM } 12 \text { - } 13 \text { Kec. } \\
\text { Tanjung Morawa } \\
\text { Kab. Deli } \\
\text { Serdang }\end{array}$ & $007 / 15 / \mathrm{K}$ & $\begin{array}{l}\text { JLN. MEDAN } \\
\text { (LUBUK } \\
\text { PAKAM) KM 0,6 }\end{array}$ & 16937 & 9 & 3 & 0 & 11 & 364 & 5.3138 & $\begin{array}{c}\text { Perkotaa } \\
\mathrm{n}\end{array}$ \\
\hline 27 & $\begin{array}{l}\text { Jalinsum Medan } \\
\text { - Rantau Prapat } \\
\text { KM } 177 \text { - } 178 \\
\text { Kec. Simpang } \\
\text { Empat Kab. } \\
\text { Asahan }\end{array}$ & 023 & $\begin{array}{c}\text { SP. KAWAT - } \\
\text { AEK KANOPAN } \\
\text { KM 3,5 - 4,5 }\end{array}$ & 8778 & 3 & 3 & 3 & 0 & 363 & 3.4176 & $\begin{array}{c}\text { Antar } \\
\text { Kota }\end{array}$ \\
\hline 28 & $\begin{array}{l}\text { Jalan Umum } \\
\text { Medan - Tebing } \\
\text { Tinggi KM } 21 \text { - } \\
22 \text { Kec. Tanjung } \\
\text { Morawa Kab. } \\
\text { Deli Serdang }\end{array}$ & 007 & $\begin{array}{c}\text { BTS. KOTA } \\
\text { MEDAN - BTS. } \\
\text { KOTA LUBUK } \\
\text { PAKAM }\end{array}$ & 11970 & 13 & 2 & 2 & 21 & 358 & 10.8605 & $\begin{array}{c}\text { Antar } \\
\text { Kota }\end{array}$ \\
\hline 29 & $\begin{array}{l}\text { Jalinsum Medan } \\
\text { - Kisaran KM } 91 \\
\text { - } 92 \text { Kec. Sei } \\
\text { Suka Kab. Batu } \\
\text { Bara }\end{array}$ & 017 & $\begin{array}{c}\text { BTS. KAB. } \\
\text { SERDANG } \\
\text { BEDAGAI - } \\
\text { TANJUNG } \\
\text { KASAU KM 0,1 - }\end{array}$ & 14288 & 8 & 2 & 4 & 14 & 358 & 5.5991 & $\begin{array}{c}\text { Antar } \\
\text { Kota }\end{array}$ \\
\hline
\end{tabular}

Prioritas Penanganan Lokasi Rawan Kecelakaan (LRK) di Provinsi Sumatera Utara (Budi Hartanto Susilo, Lutfiardi Wahyu Cahyadi) 


\begin{tabular}{|c|c|c|c|c|c|c|c|c|c|c|c|}
\hline \multirow{2}{*}{ Peringkat } & \multirow{2}{*}{ Lokasi } & \multirow{2}{*}{ No. Ruas } & \multirow{2}{*}{ Nama Ruas } & \multirow{2}{*}{ LHR } & \multirow{2}{*}{$\begin{array}{c}\text { Jumlah } \\
\text { Laka }\end{array}$} & \multicolumn{3}{|c|}{ Korban } & \multirow[t]{2}{*}{ Nilai AEK } & \multirow[t]{2}{*}{ Tk } & \multirow{2}{*}{$\begin{array}{c}\text { Segmen } \\
\text { Jalan }\end{array}$} \\
\hline & & & & & & MD & LB & LR & & & \\
\hline \multirow[t]{2}{*}{ (1) } & (2) & (3) & (4) & (5) & (6) & (7) & (8) & (9) & $\begin{array}{c}(10)= \\
(7) * 100+ \\
(8) * 20+ \\
(9) * 5+(6) * 1\end{array}$ & $\begin{array}{c}(11)= \\
((6) /(5))^{*} 1 \\
0.000\end{array}$ & (12) \\
\hline & & & 1,1 & & & & & & & & \\
\hline 30 & $\begin{array}{l}\text { Jalan Umum } \\
\text { Padangsidimpua } \\
\text { n - Panyabungan } \\
\text { KM } 16 \text { - } 17 \text { Kec. } \\
\text { Batang Angkola } \\
\text { Kab. Tapanuli } \\
\text { Selatan }\end{array}$ & 039 & $\begin{array}{c}\text { BTS. KOTA } \\
\text { PADANG } \\
\text { SIDEMPUAN - } \\
\text { BTS. KAB. } \\
\text { MADINA KM 5,9 } \\
-6,9\end{array}$ & 3935 & 4 & 3 & 2 & 2 & 354 & 10.1652 & $\begin{array}{l}\text { Antar } \\
\text { Kota }\end{array}$ \\
\hline 31 & $\begin{array}{l}\text { Jalan Medan KM } \\
02 \text { - 03 Kec. } \\
\text { Siantar Martoba } \\
\text { Kota Pematang } \\
\text { Siantar } \\
\end{array}$ & $064 / 11 / K$ & $\begin{array}{c}\text { JLN. KE MEDAN } \\
\text { (P. SIANTAR) } \\
\text { KM 2,5 }\end{array}$ & 6484 & 4 & 3 & 2 & 2 & 354 & 6.1690 & $\begin{array}{c}\text { Perkotaa } \\
n\end{array}$ \\
\hline 32 & $\begin{array}{l}\text { Jl. Jamin Ginting } \\
\text { KM } 46 \text { - } 47 \text { Kec. } \\
\text { Sibolangit Kab. } \\
\text { Deli Serdang } \\
\end{array}$ & 052 & $\begin{array}{l}\text { BTS. KOTA } \\
\text { MEDAN - BTS. } \\
\text { KAB. KARO }\end{array}$ & 5619 & 3 & 3 & 2 & 2 & 353 & 5.3390 & $\begin{array}{l}\text { Antar } \\
\text { Kota }\end{array}$ \\
\hline 33 & $\begin{array}{l}\text { Jalan Umum } \\
\text { Medan - Tanjung } \\
\text { Pura KM } 44-45 \\
\text { Kec. Wampu } \\
\end{array}$ & 003 & $\begin{array}{c}\text { TANJUNG PURA } \\
\text { - BTS. KOTA } \\
\text { STABAT KM 14,9 } \\
-15,9 \\
\end{array}$ & 14335 & 7 & 2 & 5 & 8 & 347 & 4.8832 & $\begin{array}{l}\text { Antar } \\
\text { Kota }\end{array}$ \\
\hline
\end{tabular}




\begin{tabular}{|c|c|c|c|c|c|c|c|c|c|c|c|}
\hline \multirow{2}{*}{ Peringkat } & \multirow{2}{*}{ Lokasi } & \multirow{2}{*}{ No. Ruas } & \multirow{2}{*}{ Nama Ruas } & \multirow{2}{*}{ LHR } & \multirow{2}{*}{$\begin{array}{c}\text { Jumlah } \\
\text { Laka }\end{array}$} & \multicolumn{3}{|c|}{ Korban } & \multirow[t]{2}{*}{ Nilai AEK } & \multirow[t]{2}{*}{ Tk } & \multirow{2}{*}{$\begin{array}{c}\text { Segmen } \\
\text { Jalan }\end{array}$} \\
\hline & & & & & & MD & LB & LR & & & \\
\hline \multirow[t]{2}{*}{ (1) } & (2) & (3) & (4) & (5) & (6) & (7) & (8) & (9) & $\begin{array}{c}(10)= \\
(7) * 100+ \\
(8) * 20+ \\
(9) * 5+(6) * 1\end{array}$ & $\begin{array}{c}(11)= \\
((6) /(5)) * 1 \\
0.000\end{array}$ & (12) \\
\hline & Kab. Langkat & & & & & & & & & & \\
\hline 34 & $\begin{array}{l}\text { Jalan Umum } \\
\text { Medan - } \\
\text { Tarutung KM } \\
227 \text { - 228 Kec. } \\
\text { Laguboti Kab. } \\
\text { Tobasa }\end{array}$ & 068 & $\begin{array}{c}\text { SILIMBAT - BTS. } \\
\text { KAB. TAPANULI } \\
\text { UTARA KM } 6,6 \text { - } \\
7,6\end{array}$ & 5929 & 2 & 3 & 1 & 5 & 347 & 3.3733 & $\begin{array}{c}\text { Antar } \\
\text { Kota }\end{array}$ \\
\hline 35 & $\begin{array}{l}\text { Jl. TA. Hamzah } \\
\text { KM } 26 \text { - } 27 \text { Kec. } \\
\text { Binjai Utara } \\
\text { Kota Binjai }\end{array}$ & $004 / 12 / \mathrm{K}$ & $\begin{array}{c}\text { JLN. AMIR } \\
\text { HAMZAH } \\
\text { (BINJAI) KM } 2\end{array}$ & 15883 & 5 & 3 & 1 & 4 & 345 & 3.1480 & $\begin{array}{c}\text { Perkotaa } \\
\text { n }\end{array}$ \\
\hline 36 & $\begin{array}{l}\text { Jalan Umum } \\
\text { Medan - Tebing } \\
\text { Tinggi KM } 19 \text { - } \\
20 \text { Kec. Tanjung } \\
\text { Morawa Kab. } \\
\text { Deli Serdang } \\
\end{array}$ & 007 & $\begin{array}{l}\text { BTS. KOTA } \\
\text { MEDAN - BTS. } \\
\text { KOTA LUBUK } \\
\text { PAKAM }\end{array}$ & 11970 & 10 & 2 & 1 & 22 & 340 & 8.3542 & $\begin{array}{l}\text { Antar } \\
\text { Kota }\end{array}$ \\
\hline 37 & $\begin{array}{l}\text { Jl. K.L. Yos } \\
\text { Sudarso KM } 18 \text { - } \\
19 \text { Kec. Medan } \\
\text { Labuhan Kota } \\
\end{array}$ & 009 & $\begin{array}{c}\text { MEDAN - } \\
\text { BELAWAN } \\
\text { (MEDAN) KM 2,1 } \\
-3,1 \\
\end{array}$ & 16679 & 6 & 3 & 0 & 6 & 336 & 3.5973 & $\begin{array}{l}\text { Antar } \\
\text { Kota }\end{array}$ \\
\hline
\end{tabular}




\begin{tabular}{|c|c|c|c|c|c|c|c|c|c|c|c|}
\hline \multirow{2}{*}{ Peringkat } & \multirow{2}{*}{ Lokasi } & \multirow{2}{*}{ No. Ruas } & \multirow{2}{*}{ Nama Ruas } & \multirow{2}{*}{ LHR } & \multirow{2}{*}{$\begin{array}{c}\text { Jumlah } \\
\text { Laka }\end{array}$} & \multicolumn{3}{|c|}{ Korban } & \multirow[t]{2}{*}{ Nilai AEK } & \multirow[t]{2}{*}{ Tk } & \multirow[t]{2}{*}{$\begin{array}{c}\text { Segmen } \\
\text { Jalan }\end{array}$} \\
\hline & & & & & & MD & LB & LR & & & \\
\hline \multirow[t]{2}{*}{ (1) } & (2) & (3) & (4) & (5) & (6) & (7) & (8) & (9) & $\begin{array}{c}(10)= \\
(7) * 100+ \\
(8) * 20+ \\
(9) * 5+(6) * 1\end{array}$ & $\begin{array}{c}(11)= \\
((6) /(5)) * 1 \\
0.000\end{array}$ & (12) \\
\hline & Medan & & & & & & & & & & \\
\hline 38 & $\begin{array}{l}\text { Jalan Umum } \\
\text { Medan - Tanjung } \\
\text { Pura KM 35 - } 36 \\
\text { Kec. Stabat Kab. } \\
\text { Langkat }\end{array}$ & 004 & $\begin{array}{c}\text { BTS. KOTA } \\
\text { STABAT - BTS. } \\
\text { KOTA BINJAI }\end{array}$ & 14735 & 7 & 2 & 4 & 9 & 332 & 4.7506 & $\begin{array}{c}\text { Antar } \\
\text { Kota }\end{array}$ \\
\hline 39 & $\begin{array}{l}\text { Jalan Umum } \\
\text { Kabanjahe - } \\
\text { Kotacane KM } \\
166-167 \mathrm{Kec} . \\
\text { Mardingding } \\
\text { Kab. Karo } \\
\end{array}$ & 028 & $\begin{array}{c}\text { LAWE PAKAM } \\
\text { (BTS. PROV. } \\
\text { ACEH) - KUTA } \\
\text { BULUH KM } 8,5 \text { - } \\
9,5\end{array}$ & 2761 & 2 & 3 & 1 & 1 & 327 & 7.2438 & $\begin{array}{c}\text { Antar } \\
\text { Kota }\end{array}$ \\
\hline 40 & $\begin{array}{l}\text { Jalan Umum } \\
\text { Medan - } \\
\text { Kabanjahe KM } \\
71-72 \text { Kec. } \\
\text { Kabanjahe Kab. } \\
\text { Karo }\end{array}$ & $053 / 2$ & $\begin{array}{l}\text { SP. UJUNG AJI - } \\
\text { BTS. KOTA } \\
\text { KABANJAHE } \\
\text { KM } 3,9-4,9\end{array}$ & 7232 & 5 & 3 & 0 & 3 & 320 & 6.9137 & $\begin{array}{l}\text { Antar } \\
\text { Kota }\end{array}$ \\
\hline
\end{tabular}


Tabel 3. Contoh Usulan Penanganan LRK No.1

\begin{tabular}{|c|c|c|c|c|}
\hline Peringkat & Lokasi & Pengamatan Kondisi Eksisting & Tipe Kecelakaan & Usulan Penanganan \\
\hline 1 & $\begin{array}{l}\text { Jalinsum KM } \\
34 \text { - } 35 \text { Medan } \\
\text { - Tebing Tinggi } \\
\text { Ling. Pasiran } \\
\text { Kec. } \\
\text { Perbaungan } \\
\text { Kab. Serdang } \\
\text { Bedagai. }\end{array}$ & $\begin{array}{l}\text { 1) Tipe Jalan 4/2UD dan } 2 / 2 \text { UD; } \\
\text { 2) Kondisi permukaan jalan } \\
\text { beraspal dan licin; } \\
\text { 3) Kondisi permukaan jalan di } \\
\text { jembatan rusak dan } \\
\text { bergelombang; } \\
\text { 4) Terdapat beda lebar jalan } \\
\text { sebelum dan setelah jembatan; } \\
\text { 5) Terdapat oprit; } \\
\text { 6) Terdapat persimpangan jalan } \\
\text { kemudian jalan bermedian; } \\
\text { 7) Tidak ada marka jalan; } \\
\text { 8) Tidak terdapat marka tepi } \\
\text { jalan; } \\
\text { 9) Tidak ada paku jalan; } \\
\text { 10) Banyak kendaraan besar } \\
\text { yang lewat; } \\
\text { 11) Banyak kendaraan besar } \\
\text { yang parkir ditepi jalan; } \\
\text { 12) Tata guna lahan adalah } \\
\text { pemukiman, dan pesawahan; } \\
\text { 13) Bahaya sisi jalan adalah } \\
\text { beda tinggi sisi jalan; } \\
\text { 14) Tahun pembangunan } \\
\text { eksisting adalah tahun 2016; } \\
\text { 15) Lebar jalan } \pm 14 m \text { dan } \pm\end{array}$ & $\begin{array}{l}\text { Siang hari, mobil yang saling melaju cepat } \\
\text { dan memaksa mendahului sehingga lepas } \\
\text { kendali dan terjadi tabrakan dengan mobil } \\
\text { dari arah berlawanan. } \\
\qquad>>> \\
\text { Malam hari, sepeda motor melaju cepat, } \\
\text { tiba-tiba mengerem, ditabrak dengan mobil } \\
\text { yang melaju cepat dibelakangnya, diikuti } \\
\text { truk yang menabrak mobil karena lepas } \\
\text { kendali. }\end{array}$ & $\begin{array}{l}\text { 1) Pemasang rambu: } \\
\text { - Peringatan dengan kata-kata: "Hati-hati Lokasi } \\
\text { Rawan Kecelakaan" (untuk arah menuju } \\
\text { Lubuk Pakam dan Serdang Bedagai) (Tabel II } \\
\left.(9)^{*}\right) \text {; } \\
\text { - Peringatan Jembatan (untuk arah menuju } \\
\text { Lubuk Pakam dan Serdang Bedagai) (Tabel II } \\
\left.(1 \mathrm{w})^{*}\right) \text {; } \\
\text { - Peringatan Persimpangan Tiga Sisi Kiri (untuk } \\
\text { arah menuju Serdang Bedagai) (Tabel II } \\
\left.(4 \mathrm{~b} 18)^{*}\right) \text {; } \\
\text { - Peringatan Persimpangan Tiga Sisi Kanan } \\
\text { (untuk arah menuju Lubuk Pakam) (Tabel II } \\
\left.(4 b 19)^{*}\right) \text {; } \\
\text { - Peringatan Simpang Empat Prioritas (untuk } \\
\text { arah menuju Serdang Bedagai) (Tabel II } \\
\left.(4 b 2)^{*}\right) \text {; } \\
\text { Hal ini dilakukan untuk memperingati } \\
\text { pengendara supaya berhati-hati. } \\
\text { 2) Pemasangan marka garis tengah jalan menerus } \\
\text { (warna kuning), marka batas jalur, dan marka } \\
\text { garis tepi jalan**. } \\
\text { Hal ini dilakukan untuk memperingati } \\
\text { pengendaraan akan batas lajur dan tepi jalan. } \\
\text { 3) Pemasangan paku jalan***. }\end{array}$ \\
\hline
\end{tabular}

Prioritas Penanganan Lokasi Rawan Kecelakaan (LRK) di Provinsi Sumatera Utara (Budi Hartanto Susilo, Lutfiardi Wahyu Cahyadi) 


\begin{tabular}{|c|c|c|c|c|}
\hline Peringkat & Lokasi & Pengamatan Kondisi Eksisting & Tipe Kecelakaan & Usulan Penanganan \\
\hline & & $\begin{array}{l}\text { 10m; } \\
\text { 16) Kendaraan melaju dengan } \\
\text { kecepatan antara } 16-67 \\
\text { km/jam, persentil } 85= \\
54 \mathrm{~km} / \mathrm{jam} \text {. }\end{array}$ & & $\begin{array}{l}\text { Hal ini untuk reflektor marka jalan khususnya } \\
\text { pada } \\
\text { cuaca gelap dan malam hari. } \\
\text { 4) Perbaikan permukaan jalan di jembatan yang } \\
\text { rusak bergelombang. } \\
\text { Hal ini dilakukan untuk memperlancar arus lalu } \\
\text { lintas sehingga kendaraan berjalan dengan stabil } \\
\text { dan juga terhindar dari kecelakaan yang } \\
\text { disebabkan oleh jalan rusak. }\end{array}$ \\
\hline
\end{tabular}

Keterangan:

* $\quad$ Lihat Peraturan Menteri Perhubungan Nomor 13 Tahun 2014 Tentang Rambu Lalu Lintas;

** Lihat Peraturan Menteri Perhubungan Nomor 67 Tahun 2018 Tentang Perubahan Atas Peraturan Menteri Perhubungan Nomor PM 34 Tahun 2014 Tentang Marka Jalan;

*** Lihat Peraturan Direktur Jenderal Perhubungan Darat Nomor SK.7234/AJ.401/DRJD/2013 Tentang Petunjuk Teknis Perlengkapan Jalan. 


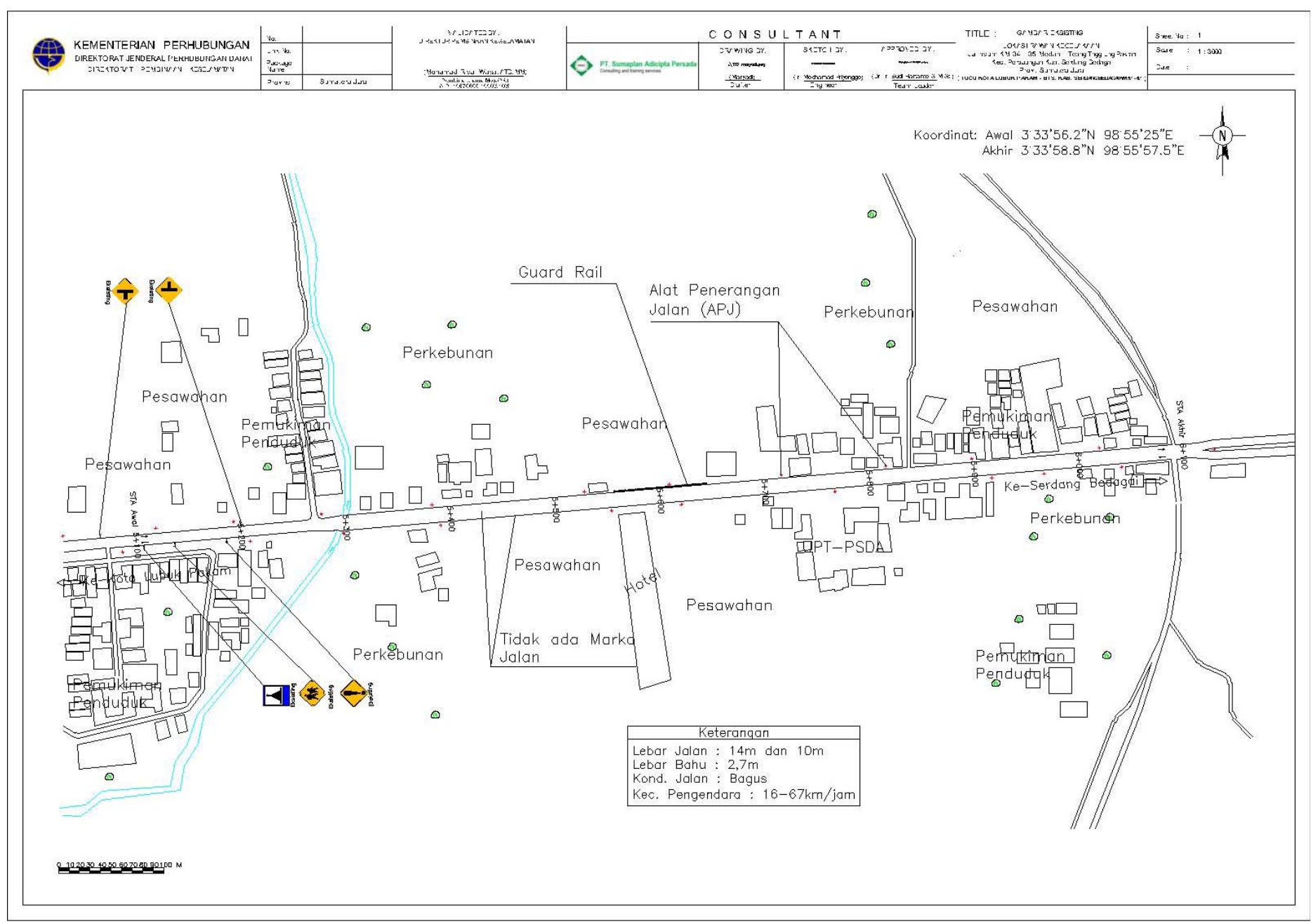

Gambar 2. Contoh Rencana Teknik Akhir (Detail Engineering Design): Eksisting LRK No.1 


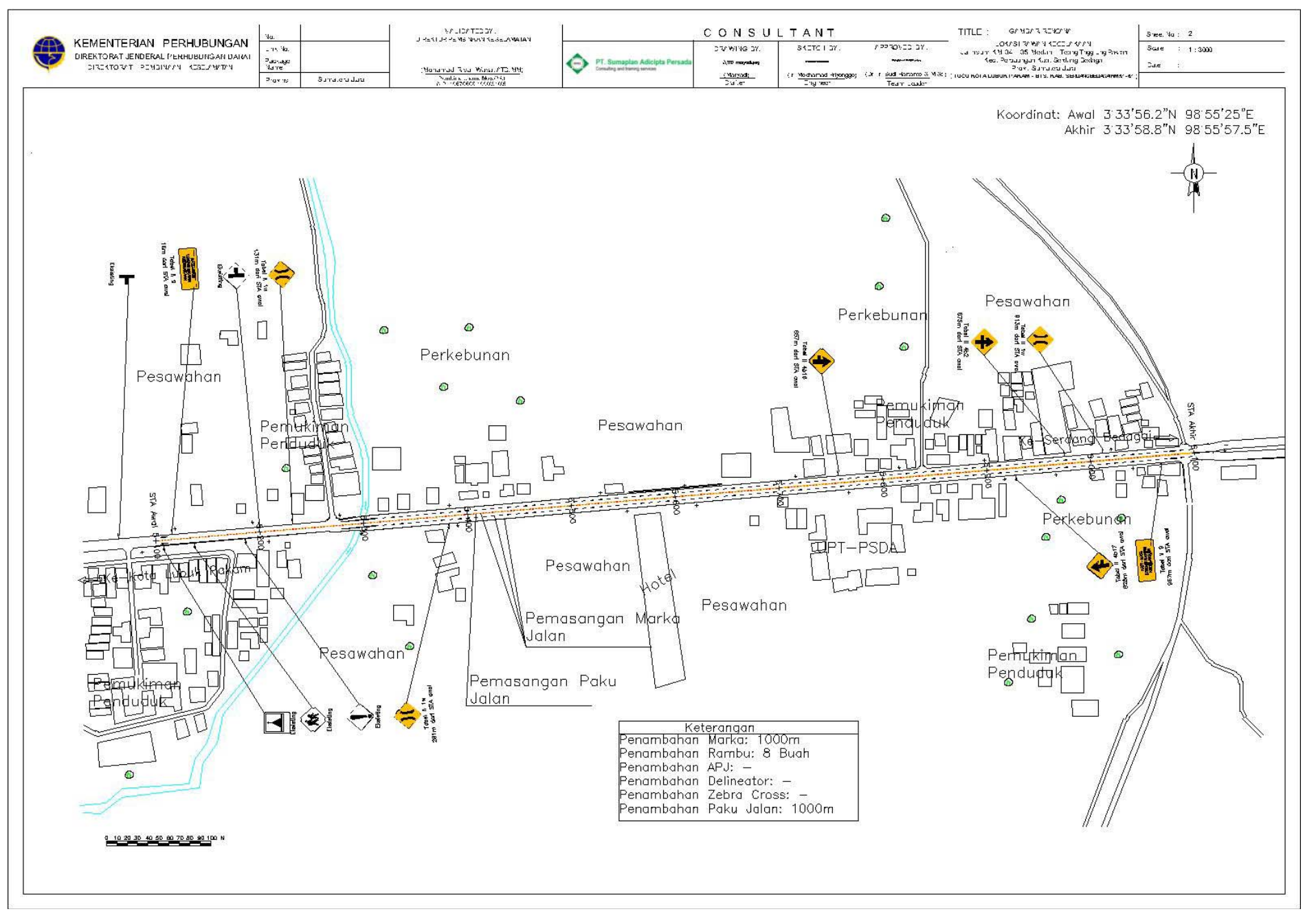

Gambar 3. Contoh Rencana Teknik Akhir (Detail Engineering Design): Rencana LRK No.1 
Tabel 4. Contoh Rincian Rencana Anggaran Biaya LRK No.1

\begin{tabular}{|c|c|c|c|c|c|c|c|}
\hline No & LRK & Usulan & Kuantitas & Satuan & $\begin{array}{c}\text { Harga } \\
\text { Satuan (R) } \\
\text { setelah } \\
\text { dengan } \\
\text { Indeks } \\
\text { Kemahala } \\
\end{array}$ & & $\begin{array}{l}\text { Jumlah } \\
\text { (Rp) }\end{array}$ \\
\hline \multirow{10}{*}{1} & \multirow{10}{*}{$\begin{array}{l}\text { Jalinsum KM } \\
34 \text { - } 35 \\
\text { Medan - } \\
\text { Tebing } \\
\text { Tinggi Ling. } \\
\text { Pasiran Kec. } \\
\text { Perbaungan } \\
\text { Kab. } \\
\text { Serdang } \\
\text { Bedagai }\end{array}$} & $\begin{array}{l}\text { Pemasangan rambu Peringatan dengan kata-kata : "Hati-hati Lokasi Rawan } \\
\text { Kecelakaan" (ukuran } 120 \text { × } 240 \mathrm{~cm} \text { ) }\end{array}$ & 2 & unit & $13,611,494$ & $\wedge$ & $27,222,988$ \\
\hline & & $\begin{array}{l}\left.\text { Pemasangan rambu Peringatan Persimpangan Jembatan (Tabel II }(1 \mathrm{w})^{*}\right)(\text { ukuran } 75 \mathrm{x} \\
75 \mathrm{~cm}) \text {. }\end{array}$ & 3 & unit & $1,420,616$ & $\wedge$ & $4,261,849$ \\
\hline & & $\begin{array}{l}\text { Pemasangan rambu Peringatan Simpang Empat Prioritas (Tabel II (4b2)*)(ukuran } 75 \mathrm{x} \\
75 \mathrm{~cm}) \text {. }\end{array}$ & 1 & unit & $1,420,616$ & $\wedge$ & $1,420,616$ \\
\hline & & $\begin{array}{l}\text { Pemasangan rambu Peringatan Persimpangan Tiga Sisi Kiri (Tabel II (4b16)*)(ukuran } \\
75 \times 75 \mathrm{~cm}) .\end{array}$ & 1 & unit & $1,420,616$ & $\wedge$ & $1,420,616$ \\
\hline & & $\begin{array}{l}\text { Pemasangan rambu Peringatan Persimpangan Tiga Sisi Kanan (Tabel II } \\
\left.(4 \mathrm{~b} 17)^{*}\right)(\text { ukuran } 75 \times 75 \mathrm{~cm})\end{array}$ & 1 & unit & $1,420,616$ & $\wedge$ & $1,420,616$ \\
\hline & & Pemasangan marka garis batas jalur (ukuran 3 x $120 \mathrm{~mm}$ ) (Thermoplastic)**. & 240 & $\mathrm{~m}^{2}$ & 33,477 & $\wedge$ & $8,034,527$ \\
\hline & & Pemasangan marka garis batas lajur (ukuran 3 x 120 mm) (Thermoplastic)**. & 196.56 & $\mathrm{~m}^{2}$ & 33,477 & $\wedge$ & $6,580,278$ \\
\hline & & $\begin{array}{l}\text { Pemasangan marka garis tepi (ukuran: tebal } 3 \text { x lebar } 120 \mathrm{~mm} \text { ) (Thermoplastic) untuk } \\
2 \text { arah**. }\end{array}$ & 240 & $\mathrm{~m}^{2}$ & 33,477 & $\wedge$ & $8,034,527$ \\
\hline & & Pemasangan paku jalan (ukuran 100 x 150 x $20 \mathrm{~mm}$ )***. & 329 & unit & 281,418 & $\wedge$ & $92,586,440$ \\
\hline & & JUMLAH & & & & & $150,982,460$ \\
\hline
\end{tabular}

Keterangan:

* Lihat Peraturan Menteri Perhubungan Nomor 13 Tahun 2014 Tentang Rambu Lalu Lintas;

** Lihat Peraturan Menteri Perhubungan Nomor 67 Tahun 2018 Tentang Perubahan Atas Peraturan Menteri Perhubungan Nomor PM 34 Tahun 2014 Tentang Marka Jalan;

*** Lihat Peraturan Direktur Jenderal Perhubungan Darat Nomor SK.7234/AJ.401/DRJD/2013 Tentang Petunjuk Teknis Perlengkapan Jalan; 


\section{SIMPULAN DAN REKOMENDASI}

\section{A. SIMPULAN}

Berdasarkan analisis tersebut maka dapat diambil kesimpulan sebagai berikut:

1. Dari data 2587 kejadian kecelakaan yang disaring bertahap menjadi 439 LRK kemudian didapat 52 LRK yang memenuhi kriteria LRK dan mengkerucut menjadi 40 LRK;

2. Dari 40 LRK terpilih dilakukan survei rinci sehingga tersusunlah Rencana Teknik Akhir (Detail Engineering Design) termasuk Rencana Anggaran Biayanya;

3. Pada tahap akhir prioritas penanganan berdasarkan pada ketersediaan dana yang ada secara bertahap.

B. REKOMENDASI:

1. Hasil kegiatan ini diharapkan dapat segera direalisasikan supaya dapat mengurangi jumlah kejadian kecelakaan di Provinsi Sumatera Utara;

2. Untuk tercapainya kegiatan LRK perlu dianggarkan dalam bentuk program paket kerja tahunan, sesuai dengan harapan INPRES Nomor 4 Tahun 2013, tentang Dekade Aksi Keselamatan, dalam periode 2011-2020.

\section{DAFTAR PUSTAKA}

1. Badan Pusat Statistik (BPS) Provinsi Sumatera Utara, 2017, Provinsi Sumatera Utara Dalam Angka 2017, Sumatera Utara;

2. Badan Pusat Statistik (BPS) Provinsi Sumatera Utara, 2018; https://sumut.bps.go.id;

3. Direktorat Jenderal Perhubungan Darat, 2014, Penyusunan Detail Engineering Design (DED) Daerah Rawan Kecelakaan Di Jalan Nasional Propinsi Lampung, Kementerian Perhubungan;

4. Direktorat Jenderal Perhubungan Darat, 2017, Penyusunan Penentuan Titik dan Rekomendasi Lokasi Rawan Kecelakaan (LRK) di Provinsi Sulawesi Tenggara, Kementerian Perhubungan;

5. Direktorat Jenderal Perhubungan Darat dan Direktorat Keselamatan Transportasi Darat, 2014, Pedoman Keselamatan Transportasi Darat: Draft Survei, Investigasi, dan Desain (SID) Lokasi Rawan Kecelakaan (LRK), Kementerian Perhubungan;

6. Instruksi Presiden Republik Indonesia Nomor 4 Tahun 2013 Tentang Program Dekade Aksi Keselamatan Jalan Presiden Republik Indonesia;

7. Keputusan Menteri Pekerjaan Umum Nomor 290 Tahun 2015;

8. Keputusan Menteri Perhubungan Nomor 34 tahun 2014 tentang Marka Jalan;

9. Peraturan Direktur Jenderal Perhubungan Darat, Nomor SK.7234/AJ.401/DRJT /2013 tentang Petunjuk Teknis Perlengkapan Jalan; 
10. Peraturan Menteri Perhubungan Nomor 13 Tahun 2014 tentang Rambu Lalu Lintas;

11. Peraturan Menteri Perhubungan Nomor 67 Tahun 2018 tentang Perubahan Atas Peraturan Menteri Perhubungan Nomor PM 34 Tahun 2014 Tentang Marka Jalan;

12. Peraturan Menteri Perhubungan Nomor 78 Tahun 2014 tentang Standar Biaya di Lingkungan kementerian Perhubungan;

13. Peraturan Pemerintah No. 34 Tahun 2006 Tentang Jalan;

14. Pusat Penelitian dan Pengembangan Prasarana Transportasi, 2004, Penanganan Lokasi Rawan Kecelakaan Lalulintas, Pd T-09-2004-B, Departemen Permukiman dan Parasarana Wilayah, Jakarta.

15. Susilo, B.H., 2016, Buku Panduan Praktis: KESELAMATAN LALU LINTAS JALAN, Pusat Studi Transportasi Antara Disiplin Ilmu di Universitas Kristen Maranatha;

16. Susilo, B.H., 2016, Guideline for Survey, Investigation, and Design of Black Spot Location (SID-BSL) and Its Application in Lampung Province, Indonesia, CIVIL ENGINEERING DIMENSION (Journal of Civil Engineering Sciece and Application);

17. Undang-Undang Nomor 22 Tahun 2009 tentang Lalu Lintas Angkutan Jalan;

18. Undang Undang No. 38 Tahun 2004 tentang Jalan.

Prioritas Penanganan Lokasi Rawan Kecelakaan (LRK) di Provinsi Sumatera Utara 